\title{
Välted seto regilaulu värsimõõdus
}

\author{
Janika Oras \\ Eesti Kirjandusmuuseumi Eesti Rahvaluule Arhiivi vanemteadur \\ janika@folklore.ee \\ Sulev Iva \\ Tartu Ülikooli eesti keele ja üldkeeleteaduse instituudi \\ lõunaeesti keele ja kultuuri lektor, Võru Instituudi teadur \\ sulev.iva@ut.ee
}

\begin{abstract}
Teesid: Artiklis vaadeldakse väldete meetrilisi omadusi kahes seto regilaulude rühmas, mille viisid kuuluvad vanemasse viisikihistusse ja koosnevad ühepikkustest, teksti silbile vastavatest nootidest. Kolme välte ja seto keele kontekstis on eri vältes sõnade jaotamiseks värsipositsioonidesse kujunenud süsteem, milles esimese- ja teisevältelisi sõnu jaotatakse ühtmoodi, kolmandavältelisi sõnu neist erinevalt. Rõhusilpide paigutamisel värsi eri positsioonidesse lähtutakse regilaulule omasest sõnarõhupaigutusest, kõigis lauludes kasutatakse üsna sageli ühte murtud värsi struktuuri $(2+3+3)$. Regilaulu kvantiteedipõhimõtted on muutunud keelekontekstis ümber tõlgendatud, aga siiski võib ka seto lauludest leida jälgi lühikeste rõhusilpide eelistamisest värsi nõrkades positsioonides.
\end{abstract}

Märksõnad: lõunaeesti fonoloogia, läänemeresoome regilaul, seto regilaul, regilaulu värsimõõt, välted eesti ja seto keeles

\section{Sissejuhatus: uurimismaterjal, -küsimused ja analüüsi põhimõtted}

Regilaulu, läänemeresoome vana suulise laulutraditsiooni põhitunnuseks on alliteratsiooni ja värsiparallelismi kõrval värsimõõt, milles rõhuliste silpide paigutamisel süllaabilisse värssi arvestatakse nende kvantiteeti. Ehkki see põhimõte kehtib kogu läänemeresoome regilaulualal, varieerub värsiehitus piirkonniti siiski märkimisväärselt ja selle põhjuseks on keelemuutused koos teiste kultuuride mõjuga (Sarv 2008, 2011).

Regilaulutraditsiooni kagupoolse ääreala Setomaa laulude värsimõõt on seni lähemalt kirjeldamata. Siinse värsi muudavad keeruliseks ja muust regi- 
laulust erinevaks seto traditsioonile omased kaheksast noodist pikemad viisid mitmesuguste eri rütmistruktuuridega. Mari Sarv on seto laulu nimetanud omaette laulukultuuriks, mida iseloomustavad osalt teistsugused värsiehituse ja viisi rütmistruktuuri vastastikuse sobitamise strateegiad, mitmehäälsus, varieeruvad rütmistruktuurid ja eepiliste laulude rohkus (Sarv 2008: 16; vrd Kuusi \& Tedre 1979: 73). Ingrid Rüütli sõnul peegeldub seto pikemates viisides võõras, mitteläänemeresoomeline alge. Pikkade lauluridade aluseks peab ta siiski kaheksasilbilist põhivärssi, mida "tundmatuseni moonutavad" rohked lisasilbid, täitesilbid ja silbijaotused (Rüütel 1988: 28-29; Pärtlas 2001: 121). Ühtlasi märgib Rüütel, et enamikus seto laulude struktuuritüüpides on ka murtud värsse, ${ }^{1}$ ehkki neid on Kagu-Eesti piirkonnale omaselt vähem kui mujal Eestis (Rüütel 1988: 32, 39-40). Ta on nimetanud Kagu-Eesti piirkonnale üldiselt omast kõrvalekaldumist regilaulu värsimõõdu kvantiteedireeglitest (ibid.: 40). Kagu-Eesti regilaulus on murtud värsse tõesti suhteliselt vähe ja suur osa lühikese algussilbiga sõnadest on paigutatud värsi tugevasse positsiooni, erinevalt regilaulu värsimõõdu ideaalmudelist (Sarv 2008, 2015).

Siinse artikli keskmes on väldete meetrilised omadused seto regilauludes. Põhiküsimus on, kuidas ja kuhu paigutatakse värsis eri vältes sõnu. Analüüsi võtavad kokku oletused seto värsimõõdu seaduspärade ning seto ja muude piirkondade regilaulu värsimõõdu tunnuste omavaheliste seoste kohta.

Artiklis vaadeldud laulud kuuluvad seto regilaulu vanemasse stiilikihistusse: viisid on enamasti pooltoon-poolteisttoon-laadis ja värsi silpidele vastavad viisis ühepikkused noodid. Isokroonne viisirütm on süllaabilise värsirütmiga üksüheselt seotud, näiteks muutub silbi lisamisel või väljajätmisel viisi pikkus (ja ühtlasi viisi meetriline vorm) rütmiühiku võrra (Pärtlas 2001: 136-139). Lähemalt vaadeldakse laule, mida on esitatud ühe kõige tuntuma lüüriliste ja jutustavate laulude viisiga (10 esitust, kokku 577 värssi; näide 1). Viisi on seto keeles nimetatud ka praasnikaviisiks ('külapüha viis, peoviis'). Siin artiklis on lühiduse huvides edaspidi kasutatud tinglikku nimetust peoviis. Salvestused pärinevad aastatest 1922-1977, traditsiooniliste laulutüüpide kõrval on valikus kolm improvisatsiooni. ${ }^{2}$ Peoviisiga lauludes on eeslauljal suhteliselt suur vabadus varieerida värsipositsioonide arvu, värsi- ja viisirütmi. Kooripartiis seevastu on stabiilselt 11 ühepikkust nooti/positsiooni. Kaheksapositsioonilisele põhivärsile lisandub kolm positsiooni, need täidetakse lisasilbi ja värsi kahe algussilbi kordusega. Alternatiivina võidakse värsi esimene silp jagada kahele noodile, nii et lisasilpi pole vaja (näide 1). ${ }^{3}$ Peoviisiga esitatud laule on võrreldud refrääniliste lõikus-, pulma- ja mängulauludega (lelotamine, kaaskôlõmine ja leigotamine, "Hobusemäng", kokku 62 esitust, 1150 värssi). ${ }^{4}$ Need laulud esindavad teist värsiehituse tüüpi, kus värsireas on enne refrääni kaheksa või seitse positsiooni, lõikuslaulus lisanduvad ka struktuursed lisa- 
Näide 1a.

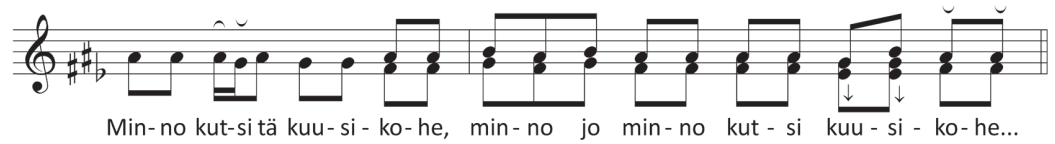

Näide $1 b$.

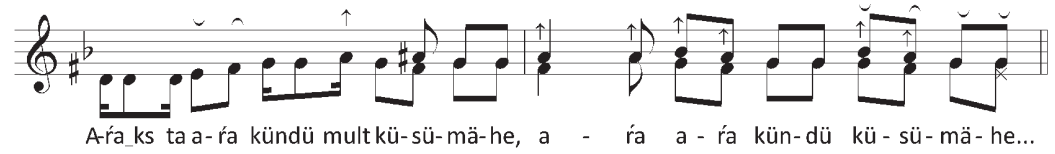

Näide 1. Peoviis ja kaks eri võimalust täita 11positsioonilise koorivärsi kolme positsiooni, mis lisanduvad põhivärsi kaheksale positsioonile: a) kahe esimese silbi kordus ja lisasilp; b) kahe esimese silbi kordus ja algussilbi jagamine kahele positsioonile. a) 'Mind kutsus ta kuusikusse', RKM, Mgn II 2295 a; b) 'Ta hakkas mult küsima', SKSÄ A 515/12-13.

silbid (Oras 2016). Analüüsil on arvestatud kõiki (ka korduvaid) arusaadavalt esitatud värsse. Eeslaulja ja koori värss on loetud üheks värsiks ja lähtutud on eelkõige kooripartiist.

Mari Sarve Eesti eri regilaulupiirkondi hõlmav värsianalüüs on tehtud kirjapandud tekstide põhjal, lähtudes n-ö keskmistest esituspõhimõtetest (nt Sarv 2008: 22-23, 2015: 11). Ehkki ka seto laulude värss on süllaabiline, takistab kirjapandud tekstide analüüsimist see, et pikemaid värsiridu koos kõigi korduste ja (värsi sisu seisukohalt kohati tähenduseta) lisasilpidega näib olevat võimatu elavas kogumisolukorras täpselt kirja panna - seda enam, et eeslaulja ja koori esitus enamasti erineb. Kirjapanekutes ei kajastu ka silbijaotused ja kiiremini lauldud silbid, ent tänu neile võivad lauljad keeleliselt sama struktuuriga värsse esitada mitut moodi. Tegemist näib olevat värsimõõdu seisukohalt võrdsete võimalustega ja raske on öelda, milline võiks olla "keskmine" interpretatsioon. Näiteks kolmandas vältes sõnu võidakse esitada kahte moodi, algussilpi jagades ja ilma: tuulõ / anni nuu / andõ $(2+3+2) \sim$ tuule / anni / nu-u / andõ $(2+2+2+2) \sim$ tuulõ / anni пuи / a-andõ $(2+3+3)$ - 'tollele andsin need anded').

Seetõttu on siin aluseks võetud laulude muusikaline esitus, ja tekste analüüsides on arvestatud positsioonidena värsimeetrumi üksusi, mis vastavad viisi meetrumiüksustele ja mida täidab enamasti üks silp. Kõigepealt 
kirjeldatakse värsside sõnarõhu paigutusest lähtuvaid põhistruktuure ning uuritakse, kas ja kuidas sõltub rõhusilpide paigutamine värsipositsioonidesse sõna vältest. Värsistruktuuride vaatluse lähtepunktiks on regilaulu kvantiteedipõhimõtted: karjala traditsioonile põhinevas regilaulu värsimõõdu mudelis on värsi tugevates, paarituarvulistes positsioonides pikad rõhusilbid ja nõrkades, paarisarvulistes positsioonides lühikesed rõhusilbid; eesti regilaulus on tänu keelemuutustele värsi tugevate positsioonide täitmine vabam, aga nõrkadesse positsioonidesse paigutatakse siiski valdavalt lühikesi rõhusilpe (Sarv 2008: 38).

Seejärel on vaatluse all eri vältes sõnade värsipositsioonidesse jaotamise põhimõtted. Uurime, mis vältes silpe võidakse koondada ühte värsipositsiooni (lauldes neid tavalisest poole kiiremini) ja millised silbid võivad täita kaks värsipositsiooni (sel juhul lauldakse silpi poole aeglasemalt, muusikalise silbijaotusega). Silpide ühte positsiooni koondamine on regilaulus tavaline. Teise juhtumi - üks silp täidab kaks positsiooni - taustaks on Võrumaa regivärsi eripära. Viimast on põhjalikult kirjeldanud Mari Sarv: Kagu-Eesti regilauludes on tavaline, et kaks värsipositsiooni täidab üks kolmandas vältes silp - mitte ainult pika vokaali või diftongiga silp, nagu regilaulus üldiselt, vaid ka lühikese vokaaliga ülipikk silp (Sarv 2008: 32-35). Keeleteadlaste uurimustele tuginedes on ta seda nähtust seostanud lõunaeesti keelemuutuste eripäraga - siinsetele murretele on omane rohke sisekadu ja selle tulemusena kolmandas vältes vormide tekkimine, kusjuures säilib kaasrõhk varasemal kolmandal, sisekaoga vormis teisel silbil (poisikõnõ > 'poiskõnõ). Seetõttu säilitab kaasrõhuline silp ka värsimõõdus värsirõhulise positsiooni (Sarv 2008: 82).

Seni on eesti regilaulu värssi uurides lähtutud põhimõttest, et värsimõõdu seisukohalt vastanduvad kahte tüüpi mitmesilbiliste sõnade algussilbid - lühikesed (eesti lauludes esimeses vältes silbid) ja pikad (eesti lauludes teises ja kolmandas vältes silbid). See on keele arengu seisukohast loogiline, sest kolme välte eristus kujunes keele lühenemise tagajärjel, regilaulu värsimõõt ja rohked regilaulus säilinud lühenemata keelevormid pärinevad varasemast ajast (nt Särg 2005: 190; Ross \& Lehiste 2001: 57-58, 131). Samas on Mari Sarv näidanud, et teise- ja kolmandavältelised silbid eristuvad Kagu-Eesti lauludes värsimõõdu seisukohalt omaette silbiklassideks (Sarv 2008: 34). Seetõttu tundus mõttekas jälgida kõigis kolmes vältes sõnade kasutamist eraldi. Välted on määratud sõnastike abil, sest lauldes silbipikkused ühtlustuvad ja kuulates on välteid raske eristada (nt Ross \& Lehiste 2001: 108, 124). ${ }^{5}$ Siiski on seto lauludes palju vanu keelevorme, milles sise- ja/või lõpukadu ei ole toimunud või on toimunud osaliselt. Neis sõnades ei saa tänapäeva keelest lähtudes väldet määrata ehkki neid on esitanud 20. sajandi laulikud, ei ole selge, kuidas nad tavakeelest erinevate vormide välteid tajusid (näiteks laulab mitu laulikut lõpukaota vormi 
meesi ilma $e$-d kõrgendamata). Neid vanu keelevorme, mis esindavad ajaloolist pikka väldet, on käsitletud omaette rühmana, tavakeeles esinevatest teises või kolmandas vältes vormidest eraldi. Lühikeses vältes vanade sõnavormide puhul polnud vaja sellist eristust teha, neid on analüüsitud esmavälteliste vormidena.

\section{Välted murtud värsistruktuuris}

Peoviisiga laulude värsid jagunevad kahte struktuuritüüpi: esiteks värsid, kus kõik mitmesilbiliste sõnade rõhusilbid asuvad 8silbilise põhivärsi paaritutes positsioonides (näide 1) ja teiseks, 2+3+3-struktuuriga murtud värsid, kus üks mitmesilbilise sõna rõhusilp on 8silbilise põhivärsi 6. positsioonis (edaspidi on seda nimetatud lihtsalt 6. positsiooniks; tegelikult on tegemist peoviisi kooripartii 9. positsiooniga, vt tabel 1). Selliseid värsse on kokku 16,8\% kõigist värssidest. ${ }^{6}$ Regilaulu muid murtud värsistruktuure $(3+2+3,3+3+2,1+3+\ldots)$ analüüsitud peoviisiga lauludes ei olnud. Võiks küsida, kui omane on murtud värsistruktuur 20. sajandi vanema põlvkonna esitajatele - kas see on pigem vanadesse lauludesse kinnistunud vorm või kasutatakse seda ka juhuimprovisatsioonides? Siinses materjalis oli traditsioonilistes tekstides veidi rohkem murtud värsse kui improvisatsioonides - vastavalt 17,7\% ja 13,6\%.

Tabel 1. Tinglikud kaheksasilbilise põhivärsi positsioonid peoviisi kooripartiis, kus tänu kordusele ja laiendusele on kokku 11 positsiooni. Mitmesilbiliste sõnade pearõhulised silbid on paksus kirjas. 'Toomas tore poisikene', 'viidi viiel sõrmel'.

\begin{tabular}{|l|l|l|l|l|l|l|l|l|l|l|l|l|}
\hline $\begin{array}{l}\text { põhivärsi } \\
\text { positsioonid }\end{array}$ & \multicolumn{3}{|c|}{$(1)}$. & 1. & 2. & 3. & 4. & 5. & 6. & 7. & 8. \\
\hline kõik positsioonid & 1. & 2. & 3. & 4. & 5. & 6. & 7. & 8. & 9. & 10. & 11. \\
\hline $2+2+2+2$ struktuur & Too- & mas & jo & Too- & mas & tor- & rõ & poi- & si- & kõ- & nõ \\
\hline $2+3+3$ struktuur & vii- & $(\mathrm{i}-)$ & di & vii- & di & vii- & e- & le & sõr- & mõ- & lõ \\
\hline
\end{tabular}

Kuna $2+3+3$ struktuuris vastab regilaulu nõrgale värsipositsioonile põhivärsi 6. positsioon, siis tekib küsimus, millises vältes sõnu sellesse positsiooni paigutatakse. Regilaulus on selles positsioonis tavaliselt lühike, esmavältelise sõna rõhuline silp. Siinsetes peoviisiga lauludes on põhivärsi 6. positsioonis kõige sagedamini samuti esimeses vältes kolmesilbilise sõna algussilp. Ent küllaltki palju on ka selliseid värsse, kus 6. positsioonist algab teises vältes kolmesilbiline sõna (tabel 2). Kolmandas vältes rõhusilpe tunduvad laulikud värsi nõrgas positsioonis vältivat (vanadest keelevormidest on värsi 6. positsioonis peaaegu eranditult kas sisekaota vormid või vormid, mille tüvekujudele vastavad tänapäeva keeles teises vältes tüved, nt kandijat 'kandjat', kaalana 'kaelas'). 2+3+3 värsside tugevas 3. positsioonis on ülekaalus pikemas vältes 
vormid, aga ka esimeses vältes sõnu on üle kolmandiku. ${ }^{7}$ Kolmandas vältes vorme on suhteliselt vähe. ${ }^{8}$

Tabel 2. Eri väldetes sõnad peoviisiga laulude põhivärsi kolmandas ja kuuendas positsioonis (värsside arv ja protsent kõigist sellest positsioonist algavatest sõnadest). Pika välte all on mõeldud raskesti määratletavat teist või kolmandat väldet, mis esineb vanades sõnavormides.

\begin{tabular}{|l|l|l|}
\hline sõnavälde & 3. positsioonis & 6. positsioonis \\
\hline esimene välde & $35(36,8 \%)$ & $64(66,0 \%)$ \\
\hline teine välde & $41(43,2 \%)$ & $24(24,7 \%)$ \\
\hline pikk välde & $13(13,7 \%)$ & $9(9,3 \%)$ \\
\hline kolmas välde & $6(6,3 \%)$ & 0 \\
\hline kokku & $95(100 \%)$ & $97(100 \%)$ \\
\hline
\end{tabular}

\section{Eri vältes sõnade jaotamine värsipositsioonidesse}

Eri vältes ja eri pikkusega sõnade värsipositsioonidesse jaotamise põhimõtted näitavad esimese ja teise välte sarnast, ning kolmanda välte erinevat meetrilist tähendust. Erinevus avaldub kõige selgemini silbijaotustes (üks silp on kahes värsipositsioonis) ja silpide kokkusurumisel (kaks silpi on ühes positsioonis).

Silbijaotusega värsse oli peoviisiga lauludes 156 (577st), kusjuures ühes värsis võib olla ka mitu silbijaotust. See arv ei sisalda struktuurseid silbijaotusi, mida osas esitustes tehakse selleks, et täita viisi alguses olevat kolmeosalist meetrumirühma, vt näide 1b. Kahte positsiooni jagatakse ühesilbilisi sõnu ja kolmandas vältes 2- ja 3silbiliste sõnade algussilpe - nii nagu mujalgi KaguEesti lauludes. Silbijaotusega ühesilbilisi sõnu oli lauludes 111, mitmesilbilisi 36 ja lisaks 20 vana vormi, mille samas käändes/pöördes tüvekujudele vastavad tavakeeles kolmandas vältes tüved. ${ }^{9}$ Ehkki enamik jagatud ülipikkadest algussilpidest sisaldavad pikka vokaali või diftongi, on Kagu-Eesti piirkonnale iseloomulikult kahte positsiooni jagatud ka lühikese vokaaliga algussilpe ( $k \boldsymbol{e}$ (e) $h v, r \boldsymbol{a}(-\boldsymbol{a}) n d a, k \boldsymbol{o}(-\boldsymbol{o})$ ttalõ 'kohale').

Pikendamist ei kasutata mitte ainult trohheilise sõnarõhuskeemiga $2+2+2+2$ värsistruktuuri, vaid ka murtud värsistruktuuri kujundamiseks. $2+2+2+2$ struktuur tekib siis, kui ühe- või kolmesilbilist sõna pikendades täidetakse vastavalt üks värsijalg või kaks värsijalga (nt saie jo / saie / kõo-o / ko(-o)t/talõ 'sai kase kohale'). Murtud värsistruktuur tekib siis, kui pikendatakse kahesilbilist sõna ja kujundatakse nii kolme värsipositsiooni täitev rõhurühm. Kahesilbilise sõna pikendamist ongi peaaegu eranditult kasutatud $2+3+3$ struktuu- 
riga murtud värsside loomiseks (jä-äse, / jääse / mi(-i)tmõst / mälehtä ‘jääb mitmeks [ajaks] mäletada'; mine jo / mine / mahlulõ / mä-ele 'mine mahlale mäele', kokku 20 värssi). ${ }^{10}$

Lisaks algussilbile võidakse pikendada ka sõna lõpusilpi. Lõpusilpi pikendatakse esimese- ja teisevältelistes kolmesilbilistes sõnades selleks, et täita neli värsipositsiooni - vastandina kolmandas vältes sõnadele, kus samal eesmärgil

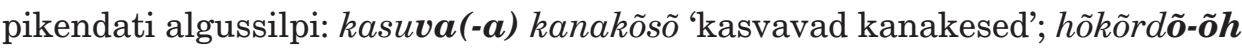
hõlma võta 'lõkerdades kaissu võtan' (10 värsis). ${ }^{11}$

Kahe silbi kokkusurumine ühte positsiooni on väga tavaline rütmistamise võte eeslaulja partiis. Eriti juhul, kui eeslaulja kasutab kokkusurumist läbivalt järjestikustes värssides, ei ole vahet, millises vältes sõnadega on tegemist. Teisiti on lugu kooripartiis, kus silpide kokkusurumist tuleb ette väga harva - siinsetes peoviisiga variantides ainult kümnes värsis (577st). Ühte positsiooni paigutatakse ainult esimeses ja teises vältes sõnade algussilpe (või sõnu): ki-ä jo / vasta / vi-il / illolõ / isi 'kes vastu veel rõõmule tuli'; ommõ jo / ommõ / kaunist / kapita / listõ 'on kaunikesti kapitaliste'. Seega paigutatakse kooripartiis nii silbijaotustes kui silpide kokkusurumisel omavahel sarnaselt esimeses ja teises vältes sõnu, neist erinevalt aga kolmandavältelisi sõnu.

Selles kontekstis tekib küsimus, kuidas üldse paigutatakse värsipositsioonidesse kolmesilbilisi sõnu, millel on regilaulu värsimõõdus eriline tähendus näiteks on murtud värsside olemasolu seostatud vajadusega leida lühikese rõhusilbiga sõnadele koht süllaabilises värsis (nt Korhonen 1999; Sarv 2015: 14). Eri vältes kolmesilbiliste sõnade paigutamise skeem illustreerib omalt poolt esimese ja teise välte sarnast ning kolmanda välte erinevat meetrilist tähendust seto värsis (tabel 3). Esimeses-teises vältes kolmesilbilisi sõnu paigutatakse eelkõige murtud värssi (vastavalt $83 \%$ ja $88 \%$ kõigist juhtudest). Kolmandas vältes kolmesilbilisi sõnu murtud värssides ei ole (ei 3. ega ka 6. positsioonis). Kõik kolmandas vältes kolmesilbilised vormid (ja samalaadsed vanad vormid) on paigutatud nii, et algussilp jagatakse kahte värsipositsiooni. Enamik neist asub põhivärsi neljas lõpupositsioonis. ${ }^{12}$ Vähem kui neljandik on neljas alguspositsioonis. Ehkki värsi esimeses pooles oleks võimalik täita neli värsipositsiooni ka kolmesilbilise ja järgneva ühesilbilise sõnaga (värsi lõpus ühesilbilisi sõnu ei ole), ei ole seda võimalust kolmandas vältes sõnade puhul kasutatud. 
Tabel 3. Kolmesilbiliste sõnade paigutamine peoviisiga lauludes. Tabelist puuduvad ühekordsed juhtumid (kullõl' jo / kullõl' / uma / ho(-o) /bõsõ 'kuulas oma hobust'; mõlõ- jo / mõlõm / bil olli / mõogga / kä-eh 'mõlemal olid mõõgad käes'). Ühte positsiooni kokku surutud silbipaar on allajoonitud. Tõlked: 'seda kõnet kõneles', 'viidi viiel sõrmel', 'kasin [saab] kasvatatud', 'kaelaehete kandjat', 'vend võttis vereva naise', 'nii vanast vallale sain', 'ei ole peene telgedele panejat', 'sai vahtra varjule', 'sulas soola maitstes', 'pärast kukkus põrgusse', 'aitüma, ole terve'.

\begin{tabular}{|c|c|c|c|c|c|c|c|c|c|c|c|}
\hline \multirow{2}{*}{$\begin{array}{l}\text { positsioonid } \\
\text { 3silbiline sõna }\end{array}$} & \multicolumn{3}{|c|}{\begin{tabular}{|l|} 
lisa- \\
positsioonid
\end{tabular}} & \multicolumn{8}{|c|}{ põhivärss } \\
\hline & (1) & $(2)$ & (3) & $1(4)$ & $2(5)$ & $3(6)$ & $4(7)$ & $5(8)$ & $6(9)$ & $7(10)$ & $8(11)$ \\
\hline \multirow[t]{3}{*}{$\begin{array}{l}\text { esimeses ja } \\
\text { teises vältes }\end{array}$} & $\begin{array}{l}\text { tu- } \\
\text { vi- }\end{array}$ & $\begin{array}{l}\text { ud } \\
\text { i- }\end{array}$ & $\begin{array}{l}\text { jo } \\
\text { di }\end{array}$ & $\begin{array}{l}\text { tu- } \\
\text { vii- }\end{array}$ & $\begin{array}{l}\text {-ud } \\
\text { di }\end{array}$ & $\begin{array}{l}\text { kõ- } \\
\text { vii- }\end{array}$ & $\begin{array}{l}\text { nõ- } \\
\text { e- }\end{array}$ & $\begin{array}{l}\text { ta } \\
\text { le }\end{array}$ & $\begin{array}{l}\text { kõ- } \\
\text { sõr- }\end{array}$ & $\begin{array}{l}\text { nõ- } \\
\text { mõ- }\end{array}$ & $\begin{array}{l}\text { li } \\
\text { lõ }\end{array}$ \\
\hline & \begin{tabular}{|l|} 
ka- \\
kaa-
\end{tabular} & $\begin{array}{l}\text { si- } \\
\text { la- }\end{array}$ & $\begin{array}{l}\text { jo } \\
\text { jo }\end{array}$ & $\begin{array}{l}\text { ka- } \\
\text { kaa- }\end{array}$ & $\begin{array}{l}\text { si- } \\
\text { lat- }\end{array}$ & $\begin{array}{l}\text { na(- } \\
\text { sõ(- }\end{array}$ & $\begin{array}{l}\text { a) } \\
\text { o) }\end{array}$ & $\begin{array}{l}\text { kas- } \\
\text { kan- }\end{array}$ & $\begin{array}{l}\text { va- } \\
\text { di- }\end{array}$ & $\begin{array}{l}\text { tõ- } \\
\text { ja- }\end{array}$ & $\begin{array}{l}\text { dus } \\
\text { ta }\end{array}$ \\
\hline & \begin{tabular}{|l|} 
vel- \\
ni-
\end{tabular} & $\begin{array}{l}\text { lo } \\
\mathrm{i}\end{array}$ & $\begin{array}{l}\text { jo } \\
\text { jo }\end{array}$ & \begin{tabular}{|l|} 
vel- \\
ni-
\end{tabular} & $\begin{array}{l}\text { lo } \\
\text { i }\end{array}$ & $\begin{array}{l}\text { võ- } \\
\text { va- } \\
\end{array}$ & $\begin{array}{l}\text { ti } \\
\text { nast }\end{array}$ & $\begin{array}{l}\text { vere- } \\
\text { valla- }\end{array}$ & $\begin{array}{l}\text { vä } \\
\text { lõ }\end{array}$ & $\begin{array}{l}\text { naa- } \\
\text { sai- }\end{array}$ & \begin{tabular}{|l} 
se \\
$\tilde{o}$ \\
\end{tabular} \\
\hline \multirow[t]{3}{*}{ pikas vältes } & pi- & i- & nü & o- & lõ-s & tsõõ- & ri- & lõ & pan- & di- & jat \\
\hline & sai- & $\mathrm{e}$ & jo & sai- & $\mathrm{e}$ & vah- & tõ- & $\mathrm{ra}$ & va- & ŕo- & lo \\
\hline & su- & las & jo & su- & las & suu- & la & ma- & it- & sõn- & na \\
\hline \multirow{2}{*}{$\begin{array}{l}\text { kolmandas } \\
\text { vältes }\end{array}$} & pe- & räst & jo & pe- & räst & sat- & tõ & põ(- & o)r-r- & go- & he \\
\hline & $\mathrm{a}(-$ & a)- & i & a- & it- & jum- & $\mathrm{ma}$ & $0-$ & lõ & ter- & ve \\
\hline
\end{tabular}

\section{Võrdlus teist tüüpi värsiehitusega refrääniliste lauludega}

Peoviisiga laulude värsiehituses on mõndagi ühist refrääniliste lauludega. Refräänita peoviisiga ja refrääniliste laulude peamiseks erinevuseks on see, et viimastes leidub rohkem kolmepositsiooniliste rõhurühmadega põhivärsi struktuure - lisaks peoviisiga laulude $2+3+3$ struktuurile veel ka $2+3+2$ ja $2+2+3$ struktuur. Viimased kaks on seitsmepositsioonilised ja neid võiks nimetada murtud värsi laadseteks struktuurideks. Sellised struktuurid näivad olevat paralleeliks regilaulu kolmeosalise rõhurühmaga algavatele struktuuridele $3+3+2$ ja $3+2+3$ - erineb esimese rõhurühma pikkus. Kuna seto vanemasse kihistusse kuuluvates lauludes on värsi alguses väga sageli nii struktuurseid kui ka juhuslikke lisasilpe, siis võiks kujutleda, et rea alguse kolmeosalist rõhurühma tajutaksegi seetõttu lisasilbiga rühmana. Kui algusrühmast üks silp välja jätta, tekibki 7positsiooniline põhivärss (olli-ks ma / jumaldõ / sajah olli /jumaldõ / sajah 'olin ma jumalate pulmas'). ${ }^{13}$ Lisaks sellistele, oletamisi "algusest lühenenud" värssidele, on siiski ka teine võimalus 7positsioonilise värsi kujundamiseks: põhivärsi teine pool (neli positsiooni) on kohati lühenda- 
tud kolmepositsiooniliseks ( higi / tulli / hi-us/sõ hõ - higi / tulli / hiussõ hõ 'higi tuli juustesse'). Ilmselt võimaldab või ajendab värsi pikkuse varieerimist refrään.

Refräänilistes lauludes on $2+3+3$ struktuuriga põhivärsside osakaal pisut väiksem kui peoviisiga lauludes (12,5\%). Eri vältes sõnu paigutatakse värsipositsioonidesse sarnaselt peoviisiga lauludele (tabel 4, vrd tabel 2). 6. positsioonis on ülekaalus esimeses vältes algussilbid, ent arvestataval hulgal on ka teises vältes algussilpe. Kolmandas vältes sõnad puuduvad. ${ }^{14}$ Nii nagu peoviisiga lauludeski, on 3. positsioonis teises vältes sõnu pisut rohkem kui esimeses vältes sõnu, kolmandas vältes sõnad on suhtelises vähemuses. Ka refrääniga lauludes on kõik 3. positsioonist algavad kolmandas vältes sõnad kahesilbilised - kanni (ta) / atra ilm / kaabulda 'kandis ta atra ilma kaabuta'). Siingi kujundatakse kolmandas vältes kahesilbilise sõna abil ka kolmepositsioonilisi rõhurühmi, jagades algussilpi kahe positsiooni vahel (tuulõ / anni nuu / a(-a)ndõ).

Tabel 4. Eri väldetes sõnad refrääniga laulude põhivärsi kolmandas ja kuuendas positsioonis (värsside arv ja protsent kõigist sellest positsioonist algavatest sõnadest).

\begin{tabular}{|l|r|r|}
\hline sõnavälde & 3. positsioonis & 6. positsioonis \\
\hline esimene välde & $49(40,0 \%)$ & $116(79,4 \%)$ \\
\hline teine välde & $63(51,2 \%)$ & $29(19,9 \%)$ \\
\hline vana vorm & $1(0,8 \%)$ & $1(0,7)$ \\
\hline kolmas välde & $10(8,1 \%)$ & 0 \\
\hline kokku & $123(100 \%)$ & $146(100 \%)$ \\
\hline
\end{tabular}

7positsioonilistest värssidest on silbijaotuste ja kokkusurumiste poolest ilmekas "lõpust lühendatud" $2+2+3$ värsside rühm. "Lõpust lühendatud" $2+2+3$ struktuur on refrääniga laulude kolmepositsioonilise rõhurühmaga struktuuridest kõige sagedasem. See on ka ainus kolmepositsiooniline rõhurühm, milles on peamiselt kolmandas vältes kolmesilbilised sõnad. Et tegemist on just lõpuosa lühendamise teel tekkinud struktuuriga, näitab see, et paljudest värssidest on olemas ka $2+2+2+2$ struktuuriga versioon. Veel enam, eeslaulja ja koor võivad laulda sama värssi erinevalt - üks pikemalt, teine lühemalt. Eri pikkusega versioonide vahele jääb ebamäärane piiriala, sest mõnede lauluridade puhul on raske aru saada, mis struktuuriga on lõpuosa - lauldakse enamvähem vahepealselt.

Lõpuosa pikemas versioonis on kolmandas vältes kolmesilbilise sõna või sellele lähedase vana vormi algussilp jagatud kahte positsiooni (selline paigutus oli peoviisi puhul reegliks). Lõpuosa lühemas versioonis algussilpi ei jagata: mullõ / anti / andita - mullõ / anti / a(-a)n/dita 'mulle anti andeid'. Ana- 
loogiliselt võidakse viimasele kahesilbilisele sõnale eelnev ühesilbiline sõna paigutada kas ühte või kahte positsiooni: kae / risti / ristimmä -ka-e / risti / ri-ist/immä 'vaata, ristiema'. Keele ajaloolist lühenemisprotsessi peegeldavad samade sõnade neljasilbilised ja (osaliselt) lühenenud kolmesilbilised versioonid värsi lõpus: kui sa / keerät / kerkohe - kui sa / keerät / keri/kohe 'kui sa keerad kirikusse' (vrd Sarv 2008: 82-83). Mõni lühenenud vorm esineb ainult laulukeeles, tavakeelne vorm on neljasilbiline: ara / vällä / västelli ‘ära välja väsitasime' - suurõ / vällä / väsü/telli 'suure välja väsitasime'.

Teine võimalus värsi lõpuosa lühendamiseks on esimeses ja teises vältes sõnade kokkusurumine ühte positsiooni. Ühte positsiooni koondatakse neljasilbilise sõna kaks esimest silpi või kahest kahesilbilisest sõnast esimene: minge / nõia / nõgõsihe-minge / nõia / nõgõ/sihe 'minge, nõiad, nõgestesse'; lipkas (no) / livva / veere pääle / / lipkas / livva / veere / pääle 'liblikas liua ääre peale'. Ka peoviisiga lauludes koondati ühte positsiooni esimeses ja teises vältes sõnade algussilpe või sõnu. Analoogia põhjal võiks ka kolme positsiooni paigutatud kolmandavältelist sõna käsitada kokkusurutud neljasilbilise sõnana, kuna silbijaotusega vormis (nt $a(-a) n-d i-t a)$ on neli "laulusilpi", millest esimene on lühike.

\section{Arutelu ja kokkuvõte}

Väldete erinevat meetrilist tähendust seto laulus - analüüsitud peoviisiga lauludes ja kolmes refrääniga laulutüübis - näitab kõige selgemini see, kuidas jaotatakse eri vältes sõnu värsipositsioonidesse (tabelid 5, 6 allpool). Siin vastanduvad esimeses ja teises vältes sõnad kolmandas vältes sõnadele. Esimeses ja teises vältes sõnu (või neljasilbiliste sõnade algussilpe) võidakse koondada ühte positsiooni, kolmandas vältes sõnadega nii ei tehta (vrd Oras 2001: 177). Kolmandas vältes sõnade algussilpe võidakse jagada kahte positsiooni, esimeses ja teises vältes sõnade puhul algussilpe ei jagata. Stabiilse pikkusega peoviisiga lauludes eristub kolmesilbiline kolmandas vältes sõna sellega, et siin jagatakse algussilp alati kahte värsipositsiooni ja sõna täidab pool värssi. See vastab Kagu-Eesti regilaulu omapärale, lõunaeesti fonoloogiast lähtuvale ülipikkade silpide paigutusele. ${ }^{15}$ Esimeses ja teises vältes kolmesilbiliste sõnade puhul seevastu jagatakse kahte värsipositsiooni lõpusilp. Ka tavakeeles on esimesel ja teisel vältel ühisjooni, mis eristavad neid kolmandast vältest: neil on sarnane põhitooni kontuur; neis pole võimalik kaasrõhk teisel silbil; teise silbi vokaal on poolpikk eelkõige esimese-, aga tihti ka teisevältelistes sõnades, kuid mitte kolmanda välte puhul (Asu et al. 2016: 142; Ross \& Lehiste 2001: 49). 
Neist põhimõtetest erinevalt paigutatakse kolmandas vältes kolmesilbilist sõna refrääniliste laulude "lühendatud lõpuga" värssides, kus 2+2+2+2 struktuurist kujundatakse $2+2+3$ struktuur. Kui lähtuda sellest, et tavaliselt on ülipikk silp laulureas jagatud kaheks "laulusilbiks", siis $2+2+3$ struktuuri puhul järgitakse esimeses vältes neljasilbilise sõna algussilpide kokkusurumise mudelit. Värsilõppude lühendamist ja seitsmepositsiooniliste värsside olemasolu üldisemalt võiks seostada refrääniga, mis annab rütmi varieerimiseks suurema vabaduse. Peab lisama, et vanema kihistuse refrääniga laulud on loomu poolest mitmekesisema rütmistruktuuriga. Veel varieeruvam on näiteks kooriga lauldud mõrsjaitku värss, mida lähemalt on käsitlenud Vaike Sarv (Pärtlas 2001: 137; Sarv 2000: 188 jj).

Tabel 5. Esimeses ja teises vältes kahe- ja kolmesilbiliste sõnade värssi paigutamine.

\begin{tabular}{|l|l|l|l|l|}
\hline Kahesilbilised sõnad & $\begin{array}{l}\text { pere } \\
\text { veere }\end{array}$ & & & \\
\hline & $\begin{array}{l}\text { pe- } \\
\text { vee- }\end{array}$ & $\begin{array}{l}\text { re } \\
\text { re }\end{array}$ & & \\
\hline Kolmesilbilised sõnad & $\begin{array}{l}\text { ilo- } \\
\text { valla- }\end{array}$ & $\begin{array}{l}\text { lo } \\
\text { lo }\end{array}$ & & \\
\hline & i- & lo- & lo & \\
\hline & val- & la- & lo & \\
\hline & ka- & si- & na(- & a) \\
\hline & kaa- & lat- & sõ(- & $\tilde{0})$ \\
\hline
\end{tabular}

Tabel 6. Ühesilbiliste ja kolmandas vältes kahe- ja kolmesilbiliste sõnade värssi paigutamine.

\begin{tabular}{|l|l|l|l|l|l|}
\hline \multirow{2}{*}{ Ühesilbilised sõnad } & rüä & & & & \\
\hline & rü- & ä & & & \\
\hline \multirow{2}{*}{ Kahesilbilised sõnad } & ham- & mõ & & & \\
\hline & ha(- & a)m- & mõ & & \\
\hline Kolmesilbilised sõnad & ko(- & o)t- & ta- & lõ & \\
\hline $\begin{array}{l}\text { Kolmesilbiline sõna + } \\
\text { refrään }\end{array}$ & kot- & ta- & lõ & refrään & \\
\hline & ko(- & o)t- & ta- & lõ & refrään \\
\hline
\end{tabular}

Kuidas paigutatakse seto lauludes eri vältes rõhusilpe värsi erinevatesse positsioonidesse ja kas siin võib leida vastavusi regivärsi kvantiteedipõhimõtetega? Murtud 2+3+3 värsistruktuuris on nii peoviisiga kui refräänilistes 
lauludes selge tendents kasutada põhivärsi 6. (regivärsimõõdu nõrgas) positsioonis eelkõige esimeses vältes sõnu ja sealt puuduvad kolmandas vältes sõnad. Põhivärsi 3. (regivärsimõõdu tugevas) positsioonis on kõigis kolmes vältes sõnu, seejuures teisevältelisi sõnu on siin esmavältelistest rohkem. Sellist paigutust võiks tõlgendada jäljena regilaulu üldistest kvantiteedipõhimõtetest: nõrka positsiooni paigutatakse eelkõige esimeses vältes rõhusilpe, tugevasse positsiooni pigem pikemaid algussilpe.

Keele kolme välte süsteemi kontekstis on seto laulude värsiehituses kujunenud esimese ja teise välte vastandus kolmandale vältele. Seda vastandust arvestades võiks väita, et ka 20. sajandi värsis järgitakse regilaulule üldiselt omast kvantiteedipõhimõtet, ehkki pisut teistsuguses vormis: põhivärsi nõrka positsiooni paigutatakse kahes lühemas, üksteisele meetriliselt sarnases vältes rõhusilpe (ja välditakse ülipikki rõhusilpe). ${ }^{16}$ Seda, et nii trohheilise sõnarõhupaigutusega kui ka murtud värsside tugevatest positsioonidest algavad kõigis väldetes sõnad, võiks eesti regilaulu kontekstis pidada loomulikuks.

Süsteemi võib tõlgendada ka teisiti: eri vältes sõnade paigutamisel ei lähtuta tugeva ja nõrga positsiooni täitmise seaduspäradest. Kolmepositsioonilised rõhurühmad on muutunud ainult sõnapaigutuse mudeliks, värsirütmi varieerimise vahendiks (vrd Sarv 2008: 37). Kolmandas vältes kolmesilbilised sõnad puuduvad 6. värsipositsioonist seetõttu, et sõnade positsioonidesse jaotamise seaduspärade järgi peaksid sellised sõnad paigutuma nelja värsipositsiooni. Aga siiski võidakse vähemalt refrääniliste laulude "lõpust lühendatud" värssides rütmi varieerimise eesmärgil paigutada kolmandas vältes kolmesilbilisi sõnu ka kolme positsiooni.

Kokkuvõttes võib seto värsist küll leida regilaulu kvantiteedisüsteemi õrna peegelduse, ent tervikuna on siiski tegemist muutunud süsteemiga. See süsteem hoiab alles murtud värsside sõnarõhupaigutuse mudeleid: värsistruktuuris on kolmepositsioonilisi rõhurühmi, mis koos kahepositsiooniliste rõhurühmadega moodustavad muude piirkondade regilauludele sarnaseid struktuure. Sõnade paigutamisel arvestatakse rõhusilbi pikkust, aga seejuures lähtutakse kolme välte süsteemist ja kohaliku keelesüsteemi kontekstis kujunenud väldete meetrilistest tähendustest. Esimese ja teise välte omavahelist meetrilist lähedust ja kolmanda välte iseseisvust peegeldavad kõige selgemini eri vältes ja eri silbiarvuga sõnade positsioonidesse jaotamise põhimõtted, sealhulgas silbipaigutuse erijuhtumid - silbijaotused ja kahe silbi koondamine ühte positsiooni. 


\section{Tänusõnad}

Kirjutise valmimist on toetanud Euroopa Liit Euroopa Regionaalarengu Fondi kaudu (Eesti-uuringute Tippkeskus), see on seotud Eesti Haridus- ja Teadusministeeriumi uurimisprojektidega IUT 22-4 ja IUT 2-37.

Suur tänu Andreas Kalkunile lahkete seto laulukeele alaste nõuannete, Mari Sarvele ja Kati Kalliole kaasamõtlemise eest!

\section{Kommentaarid}

1 Murtud värsse määratleb Ingrid Rüütel kolmesilbiliste sõnadega värssidena, neid lähemalt iseloomustamata. Tema näited on värsistruktuurist $2+3+3$, värsi 6 . positsioonist algab nii pikas kui lühikeses vältes sõna (Rüütel 1988: 32, 40).

2 “Toomalaul”, eeslaulja Marfa Sisask (kõik eeslauljad laulavad koos kooriga, märgitud on ainult eeslaulja) - kogujad I. Rüütel, O. Kiis 1973 (RKM, Mgn I 9 b); "Improvisatsioon", Hemmo Mast - H. Tampere 1953 (RKM, Mgn II 3 a); "Must naine”, Vassilissa Kõoküla - H. Tampere 1967 (RKM, Mgn II 1328 d); "Venna sõjalugu", Aleksandra Soolind - U. Kolk, V. Tormis 1970 (RKM, Mgn II 1873 c); "Vana kosilane”, Maria Tõnisson - K. Salve 1972 (RKM, Mgn II 2295 a); "Kalaranna elu", Jefimia Leigri - K. Salve 1972 (RKM, Mgn II 2298 b); "Ilolaul”, Anne Tsäro - P. Hagu jt 1977 (EKRK, Fon 96 A4); "Kolm vaest", Treiali Ode - A. O. Väisänen 1922 (SKSÄ A 515/10-11); "Improvisatsioon", Treiali Ode - A. O. Väisänen 1922 (SKSÄ A 515/12-13); “Improvisatsioon", Miko Ode - A. O. Väisänen 1922 (SKSÄ A 514/1). Viiside rütmiskeem on ühesugune, harmooniarütmilt esindavad need kahte eri viisi (vt Pärtlas 2001: 133-135). Kolme viimase salvestuse algsed litereeringud pärinevad Andreas Kalkunilt, "Kalaranna elu" ja "Venna sõjalugu" Sakarias Leppikult, täpsustused ja ülejäänud litereeringud Janika Oraselt.

${ }^{3}$ Kahe silbi kordamise põhimõttest ei peeta alati kinni. Pikem struktuur annab ka koorile võimaluse lisada oma partiisse täiendavaid sõnu. Koor võib korrata kaheksast silbist pikema eeslaulu sõnu või lisada omalt poolt sõna, mida on kasutatud samas parallelismirühmas: (eeslaulja) tuu oll' / kirjü küll / kiŕo/tõdu // (koor) tu-u jo / olli / kirjä / kiŕo/tõdu 'too oli kirja küll kirjutatud, too (jo) oli kirja kirjutatud'; (e.) ka-annõ /tigi / katõlõ / kä-ele / / (k.) ka-annõ /tigi / katõlõ / kä-ele 'kannetigi kahele käele'; (e.) karu / katõna / hulgana / / (k.) karu jo / lätsi / katõna / hulgana 'karud kahe hulgana, karud läksid kahe hulgana').

Kaldkriipsud näidetes märgivad sõnarõhurühmade algusi, kahekordne kaldkriips värsipiiri, allajoonitud silbid lauldakse poole kiiremini (kuuluvad ühte positsiooni). Sõnarõhurühma (lühemalt rõhurühma) all on mõeldud mitmesilbilise sõna rõhusilbiga algavaid kahe- või kolmepositsioonilisi (ja tavaliselt ühtlasi ka kahe- või kolmesilbilisi) rühmi värsis. Vanemates, ühepikkustest nootidest koosnevates viisides langevad teksti rõhurühmade piirid kokku muusikaliste meetrumirühmade piiridega (Pärtlas 2001: 125). Kõik siin kirjeldatud laulude viisid kuuluvad vanemasse kihistusse.

4 Seitse salvestust lõikuslaulu lühemast versioonist (128 värssi), 18 salvestust lõikuslaulu pikemast versioonist (291 värssi, nt ERmA nr 10), 26 salvestust pulmalaulust (282 värssi, nt ERmA nr 50), 11 salvestust "Hobusemängust" (449 värssi). Kõik salvestused asuvad Eesti Kirjandusmuuseumi Eesti Rahvaluule Arhiivi heliarhiivis ja need litereeris Janika Oras. 
5 Väldete määramise põhimõtted pärinevad Sulev Ivalt, kes otsustas ka keerulisemate juhtumite üle. Muus osas on kasutatud sõnastikke (Jüvä 2002; Käsi 2011, 2016), paljude sõnade ja sõnavormide osas aitas Setomaalt pärit folklorist Andreas Kalkun.

${ }^{6}$ Seda protsenti ei saa võrrelda Mari Sarve Kagu-Eesti laulude statistikaga, sest viimases on murtud värsina vaadelnud ainult neid värsse, mis vastavad kvantiteediseaduspärale - s.t värsse, kus tugevates positsioonides on pikad ja nõrkades positsioonides lühikesed rõhusilbid. Selliseid värsse on siinsetes lauludes $6,1 \%$.

7 Mari Sarve järgi on Pärnumaa, Mulgimaa ja Põhja-Viljandimaa lauludes kvantiteedireeglitele vastavate murtud värsside kõrval kvantiteedireeglitele mittevastavaid värsse, "mis sõnapaigutuselt sarnanevad murtud värssidele ning mis võivad olla kujunenudki normiks sealse piirkonna värsiehituses" (Sarv 2008: 37, 100). Muhu ja Haljala laulude põhjal (Oras 2001: 170; Ross \& Lehiste 2001: 60) on sel juhul enamasti lühike silp murtud värsi tugevas positsioonis, pikki silpe värsi nõrgas positsioonis leidub suhteliselt harva.

8 Juhul, kui kolmandas vältes sõna algussilp on jagatud kahte värsipositsiooni (nt $a(-a) n$ sõnas $a(-a) n d \tilde{o}$ 'anded'), on see silp värsistruktuuri seisukohalt loetud kaheks "laulusilbiks", millest esimene "laulusilp" on esimeses vältes (vrd Sarv 2008: 24). Siinsesse analüüsi ei mahtunud eri väldete kasutamise statistika $2+2+2+2$-struktuuriga värssides, mis annaks ülevaate kolmanda välte esinemisest ja kasutamisest seto lauludes üldisemalt.

9 Erandlikult on jagatud ka ühe esimeses ja ühe teises vältes sõna algussilpi.

10 Ühel korral kujundatakse kahe pikenduse abil trohheilise sõnarõhupaigutusega värss $k u$-a- jo / $\boldsymbol{k u}$-a/gi(-i) / ku(-u)m/bõhõ 'miski [töö ei lähe] kombe'.

${ }^{11}$ Analüüsitud peoviisi esitustes asuvad kõik sellised pikendused põhivärsi esimeses pooles. Ainus juhtum, kus pikendatakse esimeses vältes sõna algussilpi, asub just värsi teises pooles: kullõl' jo / kullõl' / uma / ho(-o) / bõsõ 'kuulas oma hobust'. Refrääniga lauludes leidub pikendatud lõpuga sõnu ka värsi teises pooles: lehe/le(-e) / lini/ge(-e) 'lakale liniku'.

12 Tuleb lisada, et regilaulukeelele omaselt on värsi neljas lõpupositsioonis rohkem siiski neljasilbilisi vorme, millest paljud on kolmesilbiliste sõnade sise- ja lõpukaota vasted (kelderennä 'keldris', nõudõmahe 'nõudma').

${ }^{13}$ Näites on eespool eeslaulja partii juhusliku lisasilbiga, seejärel kooripartii, kus lisasilpi ei laulda, sest pulma- ja mängulaulu viisis struktuurseid lisapositsioone ei ole.

${ }^{14}$ Ainus vana vormi sisaldav värss on ilma imeldä tüteri 'ilma emata tütar' (tavaline oleks: ilma imeldä kananõ 'ilma emata kanake').

${ }^{15}$ Võiks oletada, et kuna teise ja kolmanda välte eristamisel on vältuse kõrval oluline toonieristus, siis laulus, kus toon kuulub muusika vahendite hulka, on vaja teist ja kolmandat väldet selgemini pikkusega eristada. Seetõttu on kujunenud selline süsteem, kus teises vältes sõnu paigutatakse lauluvärssi kolmandas vältes sõnadest põhimõtteliselt erinevalt - ja samas sarnaselt esimeses vältes sõnadega. Teisalt on katsete teel leitud, et lõunaeestlased ongi vähemtundlikud toonierinevuste suhtes ja eristavad välteid pigem pikkussuhte põhjal (Sarv 2008: 83; Asu et al. 2016: 151-152). Kuna lauldes silbipikkused ühtlustuvad (nagu näitavad Jaan Rossi ja Ilse Lehiste andmed, muuhulgas ka seto surnuitku esituse kohta, Ross \& Lehiste 2001: 124 jm, vt ka Pino \& Sarv 1981, 1982), siis võib-olla seetõttu eristatakse kahes pikemas vältes sõnu nii selgelt laulurütmi abil. 
16 Teise välte sobimine nii nõrka kui tugevasse positsiooni meenutab Jaak Põldmäe pakutud võimalust, et teises vältes pearõhusilbid on meetriliselt neutraalsed (Põldmäe 1978: 153).

Nõrga ja tugeva positsiooni täitmise regivärsilähedase mudeli toetajatena võiks näha ka murtud värsi laadseid $2+3+2$ - ja $2+2+3$-struktuure (jättes kõrvale "lõpust lühendatud" $2+2+3$ struktuuriga värsid), mida leidub vastavalt 35 ja 10 värsis. Kui arvestada neis struktuurides värsipositsioone hüpoteetilisest 8 positsioonilisest algstruktuurist lähtudes $(3+3+2>2+3+2,3+2+3>2+2+3)$, siis oleksid need nõrgad positsioonid, kust peaks algama lühikese silbiga sõna, $2+3+2$ struktuuri keskmine ja $2+2+3$ struktuuri keskmine ja viimane sõnarõhupositsioon $(2+3+2$ ja $2+2+3)$. Just nendes positsioonides on mõlemas struktuuris ainult esimeses ja teises vältes sõnad, mõlemaid üsna võrdselt. Seevastu $2+3+2$ struktuuri viimases sõnarõhupositsioonis on kolmandik sõnu kolmandas vältes. Muidugi on tegemist ainult ühe tõlgendusvõimalusega, kust võib leida mitu nõrka kohta: (1) selline positsioonide arvestamine on tinglik; (2) neid värsse on kokku suhteliselt vähe; (3) esimest ja teist väldet on kõigis nõrkades positsioonides umbes võrdses koguses, esimene välde ei domineeri kuskil nii, nagu $2+3+3$ struktuuri 6. positsioonis.

\section{Arhiiviallikad}

\section{Eesti Kirjandusmuuseumi Eesti Rahvaluule Arhiiv:}

RKM, Mgn I - Riikliku Kirjandusmuuseumi kogu stereolindistused

RKM, Mgn II - Riikliku Kirjandusmuuseumi kogu monolindistused

EKRK, Fon - Eesti kirjanduse ja rahvaluule kateedri magnetofonilindid

\section{Soome Kirjanduse Selts:}

SKSÄ A - heliarhiivi A seeria (koopiad vaharullidelt)

\section{Kirjandus}

Asu, Eva Liina \& Lippus, Pärtel \& Pajusalu, Karl \& Teras, Pire 2016. Eesti keele hääldus. Tartu: Tartu Ülikooli Kirjastus.

ERmA = Tampere, Herbert \& Tampere, Erna \& Kõiva, Ottilie (koost) 1970. Eesti rahvamuusika antoloogia. E-väljaanne: EKM Teaduskirjastus 2016 (http://www.folklore. ee/pubte/eraamat/rahvamuusika/ee/index - 1. detsember 2017).

Jüvä, Sullõv (koost) 2002. Võro-eesti synaraamat = Võru-eesti sõnaraamat . Tartu: Eesti Kirjandusmuuseum (http://www.folklore.ee/Synaraamat/ - 28. november 2017).

Korhonen, Mikko 1999 [1987]. Kalevalamõõdu varasem ajalugu. Mäetagused 10, lk 72-89 (doi: 10.7592/MT1999.10.wkorhone).

Kuusi, Matti \& Tedre, Ülo 1979. Regivärsilise ja kalevalamõõdulise laulutraditsiooni vahekorrast. Dialoog üle lahe. Keel ja Kirjandus 2, lk 70-79. 
Käsi, Inge (koost) 2011. Vanapärase Võru murde sõnaraamat. Rõuge, Vastseliina, Setu. Tallinn: Eesti Keele Sihtasutus (www.eki.ee/dict/Voru_murde_sonaraamat.pdf 28. november 2017)

Käsi, Inge (koost) 2016. Seto sõnastik. Tallinn: Eesti Keele Instituut (http://www.eki. ee/dict/setosonastik/ - 28. november 2017).

Oras, Janika 2001. Muhu regilaulu rütmid. Jaago, Tiiu \& Sarv, Mari (toim). Regilaul keel, muusika, poeetika. Tartu: Eesti Kirjandusmuuseum, Eesti Rahvaluule Arhiiv, Tartu Ülikool, eesti ja võrdleva rahvaluule õppetool, lk 153-194.

Oras, Janika 2016. Rütmimängud ja keeleloogika. Seto regilaulu värsimõõdust. Regilaulu seitse nahka: vaateid regilaulule mitmest küljest. Regilaulukonverents 30 . novembril ja 1. detsembril 2016 Tartus, Eesti Kirjandusmuuseumis. Tartu: Eesti Kirjandusmuuseum (http://www.folklore.ee/regilaul/konverents2016/teesid2016.htm\#oras - 28. november 2017).

Põldmäe, Jaak 1978. Eesti värsiõpetus. Tallinn: Eesti Raamat.

Pino, Veera \& Sarv, Vaike 1981. Setu surnuitkud I. Tallinn: Eesti NSV Teaduste Akadeemia, Keele ja Kirjanduse Instituut.

Pino, Veera \& Sarv, Vaike 1982. Setu surnuitkud II. Tallinn: Eesti NSV Teaduste Akadeemia, Keele ja Kirjanduse Instituut.

Pärtlas, Žanna 2001. Viisi rütmilisest vormist ja laadirütmist setu mitmehäälses rahvalaulus. Jaago, Tiiu \& Sarv, Mari (toim). Regilaul - keel, muusika, poeetika. Tartu: Eesti Kirjandusmuuseum. Eesti Rahvaluule Arhiiv; Tartu Ülikooli eesti ja võrdleva rahvaluule õppetool, lk 117-152.

Ross, Jaan \& Lehiste, Ilse 2001. The Temporal Structure of Estonian Runic Songs. Lahiri, Aditi (toim). Phonology and Phonetics. Berlin, New York: Mouton de Gruyter.

Rüütel, Ingrid 1988. Setu rahvalaulu kihistused ja etnokultuuriline taust. Preprint KKI-53. Tallinn: Eesti NSV TA ühiskonnateaduste osakond.

Sarv, Mari 2008. Loomiseks loodud. Regivärsimõõt traditsiooniprotsessis. Dissertationes folkloristicae Universitatis Tartuensis 11. Tartu: Tartu Ülikooli Kirjastus (http://dspace. utlib.ee/dspace/bitstream/10062/5358/1/sarvmari.pdf - 28. november 2017).

Sarv, Mari 2011. Possible foreign influences on the Estonian regilaul metre: language or culture? Lotman, Mihhail \& Lotman, Maria-Kristiina (toim). Frontiers in Comparative Prosody. Linguistic Insights 113. Peter Lang Verlag, lk 207-226.

Sarv, Mari 2015. Regional Variation in Folkloric Meter: The Case of Estonian Runosong. RMN Newsletter 9, lk 6-17 (http://www.helsinki.fi/folkloristiikka/English/RMN/RMN_9_ Winter_2014-2015.pdf - 28. november 2017).

Sarv, Vaike 2000. Setu itkukultuur. Ars musicae popularis 14. Tartu \& Tampere: Eesti Kirjandusmuuseum, etnomusikoloogia osakond, Tampereen yliopiston kansanperinteen laitos.

Särg, Taive 2005. Eesti keele prosoodia ning teksti ja viisi seosed regilaulus. Dissertationes folkloristicae Universitatis Tartuensis 6. Tartu: Tartu Ülikooli Kirjastus (http://www. utlib.ee/ekollekt/diss/dok/2005/b17338311/sarg.pdf - 28. november 2017). 


\title{
Summary
}

\section{Quantity degrees in the metre of Seto runosong}

\author{
Janika Oras \\ Senior Research Fellow, Estonian Folklore Archives, Estonian Literary Museum \\ janika@folklore.ee

\section{Sulev Iva} \\ Lecturer in South Estonian Language and Culture \\ Institute of Estonian Language and Comparative Linguistics, University of Tartu \\ Research Fellow, Võro Institute \\ sulev.iva@ut.ee
}

Keywords: Baltic-Finnic runosong, South Estonian phonology, quantity degrees in Estonian and Seto languages, runosong metre, Seto runosong

The difference of Seto runosong from the runosong of other areas is related to specific melodies. At the same time, Seto verse is shaped by the changes in the South Estonian language. This article focuses on the songs, the melodies of which belong to an older layer of the singing tradition: these are in the one-three-semitone scale and each verse syllable corresponds to a note of the same length in the melody. As the main case, the singing performances of a melody of lyrical and epic songs, known also as the 'feast melody' (praasnikaviis), are analysed. The reference material is metrically more complicated refrain songs - harvest songs with lelo-lelo-lelo refrain (lelotamine), wedding songs with kaśke-kańke refrain (kaaskõlõmine), and game songs with heiko-leiko refrain (leigotamine, 'The Horse Game'). The main question is how the performers apply metrical entities to linguistic entities - which are the principles of placement of the words of different quantity degrees into the verse positions.

The Seto and neighbouring Võro songs resemble each other by the distinctive metrical quality of the syllables of overlong quantity degree (Q3): all Q3 initial syllables or monosyllabic words can be placed into two verse positions. In the 8-position verses of the analysed Seto songs, the initial syllables of Q3 trisyllabic words are regularly placed into two positions. The division of the initial Q3 syllable is used to form not only the regular trochaic lines, but also broken lines (lines with the word stress placement of broken lines). Seto songs feature quite evident metrical opposition between Q3 syllables and Q1-Q2 syllables. The latter are used similarly to each other - the first two syllables of Q1 and Q2 words can be assembled into one verse position and both can be placed into the "weak" positions of the line.

Related to the increasing importance of the word stress in the language, Estonian runosong has moved from a quantitative verse system towards the syllabic-accentual system and the number of broken verses is small, especially in some areas like Võrumaa (Sarv 2015). Still, in the analysed Seto songs about 15\% of the lines follow the word stress placement of the broken lines $(2+3+3$ structure). These lines do not correspond to the quantity principles of the runosong - rather, the broken line has remained a model for positioning lexical stresses. In addition, the refrain songs contain 7-position lines supposedly inspired by broken line structures. In some ways the songs with a changed 
Janika Oras, Sulev Iva

quantity system seem to conceal traces of the common quantity system of the Finnic runosong: in the weak positions of the main verse with $2+3+3$ structure, the Q1 syllables dominate (and are accompanied by a smaller number of Q2 syllables). 